\begin{tabular}{|c|l|}
\hline Title & Oxygen isotope systematics in Diploastrea heliopora: new coral archive of tropical pal eoclimate \\
\hline Author(s) & Watanabe, Tsuyoshi; Gagan, Michael K.; Corrége, Thierry; Scott-Gagan, Heather; Cowley, Joan; Hantoro, W ahyoe S. \\
\hline Citation & $\begin{array}{l}\text { Geochimica et Cosmochimica A cta, 67(7), 1349-1358 } \\
\text { https:/doi.org/10.1016/S0016-7037(02)01221-8 }\end{array}$ \\
\hline Issue Date & 2003-04-01 \\
\hline Doc URL & http://hdl.handle.net/2115/56417 \\
\hline Type & article(author version) \\
\hline File Information & GCA_67_1439.pdf \\
\hline
\end{tabular}

Instructions for use 
Geochimica et Cosmochimica Acta in press.

\title{
Oxygen isotope systematics in Diploastrea heliopora: New coral archive of tropical paleoclimate
}

\author{
Tsuyoshi Watanabe ${ }^{1,2}$, Michael K. Gagan ${ }^{1}$, Thierry Corrége ${ }^{3}$, \\ Heather Scott-Gagan ${ }^{1}$, Joan Cowley ${ }^{1}$, and Wahyoe S. Hantoro ${ }^{4}$ \\ ${ }^{1}$ Research School of Earth Sciences, The Australian National University, Canberra, ACT 0200, \\ Australia \\ ${ }^{2}$ Department of Geology, The National Science Museum, Tokyo, 169-0073, Japan \\ ${ }^{3}$ Institut de Recherche pour le Développement, Nouméa, 98800, New Caledonia \\ ${ }^{4}$ Research and Development Center for Geotechnology, Indonesian Institute of Sciences, \\ Bandung, 40135, Indonesia
}

\author{
Corresponding Author; \\ Tsuyoshi Watanabe \\ Department of Geology, The National Science Museum, Tokyo \\ 3-23-1 Hyakunin-cho, Shinjuku-ku, Tokyo 169-0073, JAPAN \\ TEL: $+81-3-5332-7164$ \\ FAX: +81-3-3364-7104 \\ E-mail: nabe@kahaku.go.jp
}


Abstract - Diploastrea heliopora forms dense, robust, dome-shaped coral colonies throughout the reef ecosystems of the tropical Pacific and Indian Oceans. This slow-growing (2-6 mm/y) coral has the potential to yield continuous paleoclimate records spanning up to 1000 years for the warmest waters on Earth, the Indo-Pacific Warm Pool, and has a long fossil history as a single recognizable species. Despite the potential of Diploastrea to be an important new paleoclimate archive, little is known about the systematics of geochemical tracers incorporated into its skeleton. In order to fill this knowledge gap, we compared skeletal $\delta^{18} \mathrm{O}$ signatures in live Diploastrea and Porites colonies from Southwest Lagoon, near Amédée Lighthouse, New Caledonia (at the southern latitudinal limit for Diploastrea) and Alor, Indonesia (in the core area of the Indo-Pacific Warm Pool). We designed a new microsampling technique to minimize smoothing and distortion of the isotopic records due to the complex calyx architecture and slow growth of Diploastrea. High-resolution isotope profiles from the septal portion of the Diploastrea corallite are attenuated, while those restricted to the central columella are similar in quality to those extracted from the well established Porites coral archive. The $\delta^{18} \mathrm{O}$-temperature relationship for the columellar portion of Diploastrea $\left(-0.18 \% /{ }^{\circ} \mathrm{C}\right)$ is in good agreement with that derived for a nearby Porites $\left(-0.19 \% /{ }^{\circ} \mathrm{C}\right.$; Quinn et al., 1996), based on comparison with an in situ sea-surface temperature record from Amédée Lighthouse, New Caledonia. There is a measurable difference of $0.3 \pm 0.1 \%$ between the kinetic / biological disequilibrium offsets from seawater $\delta^{18} \mathrm{O}$ composition for Diploastrea and Porites. Despite this offset in mean $\delta^{18} \mathrm{O}$, Diploastrea accurately records the regional differences in mean temperature and salinity between New Caledonia and the Indo-Pacific Warm Pool. Additional tests show that Diploastrea records El Niño-Southern Oscillation interannual variability in sea-surface temperature and salinity across the southwestern Pacific, indicating that it should yield dependable paleo-ENSO records. Based on these results, we propose that Diploastrea heliopora has the potential to provide an important new coral archive of tropical paleoclimate.

\section{INTRODUCTION}

Massive corals are useful paleoclimate archives because they are widely distributed throughout the tropics, can be accurately dated, and contain a wide array of geochemical tracers within their skeletons (Dunbar and Cole, 1999; Gagan et al., 2000). The quality of the evolving network of coralline paleoclimate records will inevitably depend upon its length, accuracy, and ability to resolve events spanning seasonal to century time-scales. So far, most studies of past climate have utilized the coral genus Porites because it is abundant throughout the climatically influential Indo-Pacific region and can be sampled at high temporal resolution because it grows quickly $(8-24 \mathrm{~mm} / \mathrm{y})$. At present, however, continuous geochemical records from Porites do not extend beyond the last 300-400 years (Druffel and Griffin, 1993; Linsley et al., 1994; Quinn et al., 1998; Hendy et al., 2002). The same age barrier has been met in published studies of Pavona from the equatorial eastern Pacific (Dunbar et al., 1994) and Montastraea from the Caribbean (Watanabe et al., 2000; Winter et al., 2000).

Recently, there has been a concerted effort to develop isotopic techniques appropriate for exceptionally slow-growing $(0.2-1.0 \mathrm{~mm} / \mathrm{y})$ coralline sponges (Böhm et al., 2000), which can live for more than 400 years (Swart et al., 1998). While coralline sponges appear to be well-suited for recording century to decadal-scale climate changes (Böhm et al., 1996; Moore et al., 2000), they lack annual density bands and must be dated radiometrically, thus potentially limiting their accuracy as recorders of seasonal to interannual climate variability. Also, coralline sponges are not abundant in the fossil record, which limits their ability to provide time-slice reconstructions of Late Quaternary climates. 
On the other hand, the massive annually banded coral Diploastrea heliopora is known to live for up to 1000 years (T. Corrége, unpublished data) and has inhabited the tropical reef ecosystems of the Indian Ocean, Caribbean Sea, and Tethys Sea since the Oligocene as a single distinctive species (Veron, 2000). Today, Diploastrea is common throughout the tropical Indian and Pacific Oceans and grows slowly $(2-6 \mathrm{~mm} / \mathrm{y})$, even in the warm waters of the Indo-Pacific Warm Pool where the coral Porites tends to grow quickly and die relatively young. Diploastrea is known to be less prone to boring organisms and grazing fish than Porites (Veron, 2000). The robust, dense skeleton of Diploastrea is also well preserved in Late Quaternary raised coral reefs within the Warm Pool region, including Indonesia (Chappell and Veeh, 1978; Pirazzoli et al., 1991; Hantoro et al., 1994), Papua New Guinea (Chappell, 1974), and Vanuatu (Burr et al., 1998; Cabioch et al., 1998).

Despite the potential of Diploastrea heliopora to advance our understanding of tropical climate variability, little is known about its geochemistry, with the exception of a study of radiocarbon variability in a fossil Diploastrea from the raised reefs of Espiritu Santo, Vanuatu (Burr et al., 1998). In this study we test the ability of $\delta^{18} \mathrm{O}$ in Diploastrea to record the full range in the temperature and oxygen isotopic composition of seawater (Epstein et al., 1951; Weber and Woodhead, 1972) across its known range of survival (Fig. 1). We experimented with microsampling protocols for Diploastrea specimens from two different physiographic and oceanic settings; the Southwest Lagoon, near Amédée Lighthouse, New Caledonia, at the southern latitudinal limit for Diploastrea and Alor, Indonesia, in the core area of the Indo-Pacific Warm Pool. The oxygen isotope systematics for the coral Porites are reasonably well established for the western Pacific region, so we produced oxygen isotope records for pairs of Diploastrea and Porites from both oceanic settings to compare the quality of the isotopic signals recorded by the two corals.

\subsection{Southwest Lagoon, New Caledonia}

\section{STUDY AREA}

A continuous core of Diploastrea heliopora was collected on 29 March 1996 using an underwater hydraulic drill in the Southwest Lagoon of New Caledonia, $15 \mathrm{~km}$ northwest of Amédée Lighthouse $\left(22^{\circ} 29^{\prime} \mathrm{S}, 1^{\prime} 66^{\circ} 27^{\prime} \mathrm{E}\right.$; Fig. 1). This specimen of Diploastrea grew in an open, well-flushed reef environment at a depth of $\sim 3 \mathrm{~m}$ below mean low tide. We compare the oxygen isotope record for the Diploastrea with the oxygen isotope record of Quinn et al. (1996) for a Porites growing in a similar reef environment $4 \mathrm{~km}$ from Amédée. Sea surface temperature (SST) and sea surface salinity (SSS) have been monitored almost continuously at Amédée Lighthouse since 28 February 1967 by the Institut de Recherche pour le Développement. The in situ SST record is used to establish the temperature dependence of $\delta^{18} \mathrm{O}$ in Diploastrea heliopora. Mean SST at Amédée during the calibration period (1980 to 1996) was $23.4^{\circ} \mathrm{C}$, with a mean seasonal range of $5.2^{\circ} \mathrm{C}$. New Caledonia is located on the southeastern pole of the Asian-Australian monsoon system and receives annual average rainfall of $1050 \mathrm{~mm}$, with an average monthly maximum of $150 \mathrm{~mm}$ in March, and a minimum of $40 \mathrm{~mm}$ in September. Despite the seasonal rainfall, SSS at Amédée from 1980 to 1996 was a relatively constant 35.7 PSU, with an average seasonal range of 0.6 PSU.

\subsection{Alor, Indonesia}

An underwater hydraulic drill was deployed to retrieve vertical cores from live colonies of Diploastrea heliopora and Porites on 13-14 September 1999 from the fringing reef at Pantai Putih, Alor, Indonesia $\left(8^{\circ} 14^{\prime} \mathrm{S}, 124^{\circ} 24^{\prime} \mathrm{E}\right.$; Fig. 1) for comparison with the coral $\delta^{18} \mathrm{O}$ records 
from New Caledonia. The Diploastrea and Porites were located $\sim 50 \mathrm{~m}$ apart in similar water depths (tops of colonies 2.5-3.5 m below mean low tide) to ensure both coral specimens grew in comparable reef environments. The ocean water surrounding Alor is among the warmest on Earth; mean SST for the $1^{\circ} \mathrm{x} 1^{\circ}$ box centered at $124.5^{\circ} \mathrm{E}, 8.5^{\circ} \mathrm{S}$ (IGOSS NMC blended ship and satellite data; Reynolds and Smith, 1994) was $28.3^{\circ} \mathrm{C}\left(2.3^{\circ} \mathrm{C}\right.$ range $)$ for the calibration period 1985 to 1999 , which is $4.9^{\circ} \mathrm{C}$ warmer than the mean SST of New Caledonia. Monsoon rainfall is higher in Alor than in New Caledonia, averaging $2000 \mathrm{~mm} / \mathrm{y}$, and highly seasonal with an average monthly maximum of $245 \mathrm{~mm}$ in March, and a minimum of $16 \mathrm{~mm}$ in September. Mean SSS in Alor (34.3 PSU), estimated from the NOAA National Center for Environmental Prediction satellite data, is substantially lower (1.4 PSU) than the mean salinity at Amédée, New Caledonia.

\section{MATERIALS AND METHODS}

\subsection{Skeletal Architecture and Sampling Considerations}

Colonies of Diploastrea heliopora are easily identified in the reef environment by their dome-shaped habit, smooth growth surfaces, and convex corallites (Veron, 2000). Individual corallites are $\sim 10 \mathrm{~mm}$ in diameter. Each corallite comprises a straight, prominent columella $(\sim 3$ $\mathrm{mm}$ dia.) surrounded by radiating septa that thicken toward the corallite wall. Upper growth surfaces of septa slope downward from the columella at an angle of $\sim 45^{\circ}$ forming $\sim 5 \mathrm{~mm}$-high cone-shaped tops. The important point is that the sloping growth surfaces in the septal region of the corallite are not perpendicular to the main direction of coral growth. Thus it became clear that microsampling of both columellar and septal skeletal elements would produce a complex paleoenvironmental record reflecting a mixture of carbonate material precipitated over a period of several months.

In order to address this issue, we designed a microsampling approach to investigate the nature of the isotopic signals retrieved from the columellar versus septal areas of Diploastrea heliopora. All cores were slabbed at $7 \mathrm{~mm}$ thickness parallel to the axis of maximum growth and x-rayed. In addition to showing the position of the columellar and septal areas of Diploastrea, the x-rays revealed distinct density band couplets that are four to five times narrower than those in Porites growing in the same reef setting (Fig. 2). To test for the potential effect of signal smoothing in the septal area of Diploastrea, we prepared two parallel sampling transects, one restricted to the columella and the other restricted to the septal area of the corallite. The experiment was carried out on the Diploastrea from New Caledonia, where seasonal variations in SST are large and any smoothing of the $\delta^{18} \mathrm{O}$ signal in the septal region should be obvious. We adopted the ledge microsampling technique of Gagan et al. (1994) whereby a $2 \mathrm{~mm}$ thick ledge is prepared and ultrasonically cleaned prior to microsampling (Fig. 2). This was accomplished by immersing the coral slab in distilled water and focusing a powerful ultrasonic beam repeatedly onto either side of the ledge to remove surficial contaminants and, in the case of Porites, to disintegrate dissepiments. Horizontal dissepiments are precipitated near the base of the living coral tissue at depth within the skeleton of Porites and, if they are not selectively removed, can potentially cause substantial smoothing of the isotopic record (Barnes and Lough, 1993; Gagan et al., 1994).

\subsection{Microsampling Technique: Columella versus Septa}

Computer-controlled microsamples of $100 \mu \mathrm{m}$ thickness were collected from both columellar and septal transects in the New Caledonia Diploastrea to ensure the records were comparable at $\sim 25$ samples per annual growth increment, based on the width of density band couplets observed in X-radiographs. In the first instance, the anastomosing network of skeletal elements forming 
the columella was shaved continuously along a strip with a $2 \mathrm{~mm}$ x $2 \mathrm{~mm}$ cross-sectional area centered within the columella. In order to obtain a clean cut, and samples of equal mass $(\sim 400$ $\mu \mathrm{g})$, we used a slowly rotating (90 RPM) $2 \mathrm{~mm}$ diameter end-mill bit that traverses slowly $(0.2$ $\mathrm{mm} / \mathrm{s}$ ) across the cutting surface. After the sample powder was collected, an additional $1 \mathrm{~mm}$ was cut and discarded to ensure the next sample was collected from a flat cutting surface. An identical protocol was used to collect microsamples from a septal transect adjacent to the columellar sampling transect.

Microsamples for the Diploastrea and Porites specimens from Alor were collected in the same manner and at a frequency ( $\sim 25$ samples/y) comparable with that used for the Diploastrea from New Caledonia. The sampling frequency for the Porites from New Caledonia is $\sim 12$ samples/y (Quinn et al., 1996).

\subsection{Oxygen and Carbon Isotope Analysis}

$180-220 \mu \mathrm{g}$ aliquots of samples were analyzed for oxygen $\left(\delta^{18} \mathrm{O}\right)$ and carbon $\left(\delta^{13} \mathrm{C}\right)$ isotope ratios by reacting the powders with $103 \%$ phosphoric acid at $90^{\circ} \mathrm{C}$ using an automated individual-carbonate reaction device (Kiel device) coupled to a Finnigan MAT 251 mass spectrometer. Isotopic ratios are expressed in conventional delta notation in \%o units relative to Vienna Peedee Belemnite (V-PDB) through measurements of the isotopic ratio of $\mathrm{CO}_{2}$ gas derived from National Bureau of Standards NBS-19 ( $\delta^{18} \mathrm{O}:-2.20 \% ; \delta^{13} \mathrm{C}: 1.95 \%$ ) and NBS-18 $\left(\delta^{18} \mathrm{O}:-23.00 \%\right.$; $\delta^{13} \mathrm{C}:-5.00 \%$ ). Average internal precision for NBS-19 was $0.04 \%$ o for $\delta^{18} \mathrm{O}$ and $0.04 \%$ for $\delta^{13} \mathrm{C}(\mathrm{n}=158)$ during the course of the measurements.

The oxygen isotopic analysis of seawater followed a modified version of the $\mathrm{H}_{2} \mathrm{O}-\mathrm{CO}_{2}$ equilibration technique (Epstein and Mayeda, 1953) described by Socki et al. (1992). $3 \mathrm{ml}$ water samples were equilibrated with $7 \mathrm{ml}$ of $\mathrm{CO}_{2}$ gas for $\sim 40$ hours at $25.0 \pm 0.1^{\circ} \mathrm{C}$. The equilibrated $\mathrm{H}_{2} \mathrm{O}-\mathrm{CO}_{2}$ gas was then injected into a vacuum line for $\mathrm{CO}_{2}$ extraction. The $\delta^{18} \mathrm{O}$ value of the purified $\mathrm{CO}_{2}$ was measured on a Finnigan MAT 251 and expressed relative to Vienna Standard Mean Ocean Water (V-SMOW).

\section{RESULTS AND DISCUSSION}

\subsection{Oxygen Isotope Ratios in Columella versus Septa}

Figure 3 shows $\delta^{18} \mathrm{O}$ and $\delta^{13} \mathrm{C}$ profiles for the columella and septa in the same corallite of the Diploastrea heliopora from New Caledonia over five annual growth increments (1991-1995). The results demonstrate that the seasonal range in $\delta^{18} \mathrm{O}$ and $\delta^{13} \mathrm{C}$ from the septal sampling transect is significantly attenuated relative to that of the columella. In addition, the position of the isotopic seasonal cycle is offset between the columellar and septal sampling transects, in terms of its distance from the outer growth surface of the coral. Isotopic signals extracted from skeleton residing mid-way within the living tissue layer at the time the coral was collected are offset by about one-half of a seasonal cycle ( $\sim 6$ months). Signals that have passed through the entire tissue layer are offset by about one full seasonal cycle ( $\sim 12$ months).

The smoothing and offset in position of the $\delta^{18} \mathrm{O}$ and $\delta^{13} \mathrm{C}$ records extracted from the septa of Diploastrea, relative to that from the columella, is likely to be caused by two factors; corallite geometry and calcification at depth within the tissue layer. The $\sim 45^{\circ}$ inclination of the growth surfaces of septa relative to the direction of coral growth means that each microsample contains skeleton precipitated over a longer period of time compared to microsamples collected within the columella. An additional smoothing process could involve the thickening of septa through time as they pass through the tissue layer, as has been observed to some extent for Porites (Barnes and 
Lough, 1993). In Diploastrea, the bulk of septal calcification appears to occur near their outer edge and base where the septa thicken and interlock with other septa along the walls of adjacent corallites. This basal thickening of the septa in Diploastrea, and their $\sim 45^{\circ}$ inclination, may explain the offset of about one-half of a seasonal cycle between isotopic profiles produced from septal and columellar transects. The specimen from New Caledonia grows at $\sim 3 \mathrm{~mm} / \mathrm{y}$ (see section 4.2). Thus, for the case of the Diploastrea used in this experiment, the septal record reflects the concentration of calcification toward the base of the septa, $1.5-3.0 \mathrm{~mm}$ down from the top of the columella, a distance which is equivalent to about one-half to one seasonal cycle in $\delta^{18} \mathrm{O}$ and $\delta^{13} \mathrm{C}$.

These results agree with studies of Montastraea where it has been found that skeletal structures may calcify at different times and that the amplitude of the seasonal $\delta^{18} \mathrm{O}$ profile produced by bulk sampling is significantly reduced and irregular (Pätzold, 1992; Leder et al., 1996; Watanabe et al., 2002). However, attenuation of isotopic signals in Diploastrea heliopora can be avoided because the large corallite and distinct separation of columellar and septal structures allow samples to be collected from specific skeletal elements. The results indicate that calcification in the columella may be primarily restricted to the area at the top of the corallite. Therefore only columellar skeletal elements should be sampled in order to minimize any smoothing and distortion of the isotopic signal caused by the complex corallite architecture and slow-growth of Diploastrea.

\subsection{Skeletal Calcification Rate and Oxygen Isotope Disequilibrium}

It has been shown that corals do not precipitate their skeletons in isotopic equilibrium with ambient seawater (Weber and Woodhead, 1972; Land et al., 1975; Goreau, 1977; Erez, 1978; Swart, 1983; McConnaughey, 1989a,b; Heikoop et al., 2000). The result of this isotopic disequilibrium in corals is the simultaneous depletion of the heavy isotopes ${ }^{13} \mathrm{C}$ and ${ }^{18} \mathrm{O}$ during the $\mathrm{CO}_{2}$ hydration and hydroxylation reactions involved in calcification (McConnaughey, 1989a,b). In the case of oxygen isotopes, it has been suggested that this kinetic offset from equilibrium is constant within a given coral genus (Weber and Woodhead, 1972). However, there is evidence that kinetic isotope or 'vital effects' are not necessarily constant within a coral genus, or even within individual coral colonies (McConnaughey, 1989a; Aharon, 1991; de Villiers et al., 1995; Wellington et al., 1996; Cohen and Hart, 1997; Guilderson and Schrag, 1999; Linsley et al., 1999).

A key question is whether biological controls on ${ }^{18} \mathrm{O} /{ }^{16} \mathrm{O}$ fractionation are sufficiently constant within a coral genus across its known range of survival to utilize a given coral for paleoclimate reconstruction. This study was designed to determine if the $\delta^{18} \mathrm{O}$ values for slow-growing Diploastrea heliopora are consistently offset from those of the faster growing Porites. It has been shown that faster growing parts of coral skeletons, or faster growing coral colonies, tend to be more strongly depleted in ${ }^{18} \mathrm{O}$ (e.g., McConnaughey 1989a). Thus differences in the mean $\delta^{18} \mathrm{O}$ values of Diploastrea and Porites growing in identical reef environments should be indicative of the difference in the effect of biologically mediated fractionation of ${ }^{18} \mathrm{O} /{ }^{16} \mathrm{O}$ for the two coral genera.

Annual skeletal extension rates were estimated for the paired specimens of Diploastrea and Porites from New Caledonia and Alor based on the distance between $\delta^{18} \mathrm{O}$ maxima (Fig. 4), which correspond to winter SST minima. The average annual extension rate for the New Caledonia Diploastrea was $2.7 \mathrm{~mm} / \mathrm{y}$ (range 2.1-3.4 mm/y), whereas the nearby Porites grew $\sim 4$ times faster $(10.5 \mathrm{~mm} / \mathrm{y}$, range 6.2-13.4 mm/y; Quinn et al., 1996). In Alor, the average annual 
extension rate for the Diploastrea was $3.8 \mathrm{~mm} / \mathrm{y}$ (range 2.4-6.4 mm/y) while the adjacent Porites grew $\sim 5$ times faster $(20.4 \mathrm{~mm} / \mathrm{y}$, range $16.8-23.2 \mathrm{~mm} / \mathrm{y})$. Such large differences in coral extension rate $(3-23 \mathrm{~mm} / \mathrm{y})$ should result in significantly different kinetic fractionation of ${ }^{18} \mathrm{O}$ (McConnaughey, 1989a).

The average $\delta^{18} \mathrm{O}$ values for the Diploastrea and Porites (Quinn et al., 1996) from New Caledonia are $-4.03 \%$ and $-4.42 \%$, respectively, giving a difference of $0.39 \%$ (Fig. 4 ). For comparison, the average $\delta^{18} \mathrm{O}$ values for the Diploastrea and Porites from Alor are $-5.27 \%$ and $-5.52 \%$, respectively, giving a difference of $0.25 \%$. Disregarding the possibility that part of the difference in the mean $\delta{ }^{18} \mathrm{O}$ values for the Diploastrea and Porites from New Caledonia may be due to interlaboratory calibration differences (Ostermann and Curry, 2000), the results suggest that the disequilibrium offset in $\delta^{18} \mathrm{O}$ between Diploastrea and Porites is $0.3 \pm 0.1 \%$.

The results agree with kinetic isotope disequilibrium models (McConnaughey, 1989a,b), which predict that slow-growing corals should approach isotopic equilibrium and be preferentially enriched in ${ }^{18} \mathrm{O}$. The difference in mean $\delta^{18} \mathrm{O}$ for Diploastrea and Porites is surprisingly small, however, considering the vast difference in their extension rates. One possibility is that the relatively high skeletal bulk density of Diploastrea is compensating, in part, for the reduction in extension rate. The Diploastrea examined in this study both have bulk densities of $\sim 1.8 \mathrm{~g} / \mathrm{cm}^{3}$ (determined gravimetrically), which are $\sim 50 \%$ greater than densities typical for Porites $\left(1.2 \pm 0.2 \mathrm{~g} / \mathrm{cm}^{3}\right)$, as measured throughout the Great Barrier Reef, Australia (Lough and Barnes, 1997). Applying these densities to the coral specimens from New Caledonia and Alor yields calcification rates (density x extension rate) of $0.49-0.68 \mathrm{~g} / \mathrm{cm}^{2} / \mathrm{y}$ for Diploastrea and $1.26-2.45 \mathrm{~g} / \mathrm{cm}^{2} / \mathrm{y}$ for Porites. Clearly the difference in bulk density between the coral genera is insufficient to compensate completely for the 4-5 fold difference in calcification indicated by coral extension rates. Another possibility is that the columellar skeletal elements of Diploastrea may calcify at a mean rate similar to the bulk calcification rate of Porites. $\quad$ Regardless of the exact controls for the offset in $\delta^{18} \mathrm{O}$, the consistent results across a range of environmental settings suggest that this offset is sufficiently constant in Diploastrea to allow this coral to be explored further for the purposes of paleoclimate reconstruction.

\subsection{Temperature-dependence of $\delta^{18} \mathrm{O}$ in Diploastrea}

We calibrated the relationship between $\delta^{18} \mathrm{O}$ in Diploastrea and in situ measurements of temperature at Amédée Lighthouse by comparing minima and maxima in coral $\delta^{18} \mathrm{O}$ with corresponding peaks and troughs in SST for 15 seasonal cycles from 1980 to 1995 (Fig. 5). Distance along the coral sampling transect was converted to time assuming each peak and trough in the coral $\delta^{18} \mathrm{O}$ profile corresponds to the average arrival-time of summer and winter SSTs, respectively. The Analyseries program (Paillard et al., 1996) was used to interpolate linearly between summer and winter anchor-points in the coral record to produce a resolution of 12 samples per year to match the resolution of the in situ SST record.

The least squares regression equation for the temperature-dependence of $\delta^{18} \mathrm{O}$ for the New Caledonia Diploastrea $\left(\delta^{18} \mathrm{O}_{\mathrm{c}}\right)$ is:

$$
\delta^{18} \mathrm{O}_{\mathrm{c}}=0.23-0.18 * \mathrm{~T}\left({ }^{\circ} \mathrm{C}\right) \quad(\mathrm{r}=0.94)
$$

The slope of the $\delta^{18} \mathrm{O}$-temperature calibration $\left(-0.18 \%{ }^{\circ} \mathrm{C}\right)$ is in good agreement with that derived for the Porites from Amédée $\left(-0.19 \%{ }^{\circ} \mathrm{C}\right.$; Fig. 6) analyzed at high sample resolution by Quinn et al. (1996). Seasonal variations in $\delta^{18} \mathrm{O}$ recorded by the Diploastrea and Porites in 
New Caledonia are likely to be driven primarily by variations in temperature because the effect of SST variations on coral $\delta^{18} \mathrm{O}$ is large relative to those brought about by variations of $\delta^{18} \mathrm{O}$ in seawater $\left(\delta^{18} \mathrm{O}_{\mathrm{w}}\right)$. In the tropical Pacific, $\delta^{18} \mathrm{O}_{\mathrm{w}}$ is strongly related to surface-ocean salinity (SSS) with the following regression equation (Fairbanks et al., 1997):

$$
\delta^{18} \mathrm{O}_{\mathrm{w}}=-9.14+0.273 * \mathrm{SSS} \quad\left(\mathrm{r}^{2}=0.92\right)
$$

Applying this $\delta^{18} \mathrm{O}_{\mathrm{w}}$-SSS relation to the in situ salinity record for Amédée yields average seasonal variations in $\delta^{18} \mathrm{O}_{\mathrm{w}}$ of $0.16 \%$. Although the seasonal variation in $\delta^{18} \mathrm{O}_{\mathrm{w}}$ is not small relative to the mean seasonal range in $\delta^{18} \mathrm{O}_{\mathrm{c}}$ for the Diploastrea $(0.82 \%$; 1980-96) and Porites $\left(0.77 \% ;\right.$; 1980-92), its influence on the $\delta^{18} \mathrm{O}_{\mathrm{c}}$-SST calculation is negligible. This is because the difference in SSS in February (35.63 PSU) and August (35.83 PSU), which are the times of the SST maxima and minima used for the $\delta^{18} \mathrm{O}_{\mathrm{c}}$-SST calculation, corresponds to only $0.06 \%$ change in $\delta^{18} \mathrm{O}_{\mathrm{w}}$. The results suggest that high-resolution measurements of $\delta^{18} \mathrm{O}$ in the columellar skeletal elements of Diploastrea heliopora will yield estimates of seasonal variations in paleotemperature comparable with those extracted from Porites.

\subsection{Reconstructing Regional Differences in Temperature and Salinity}

One of the goals of this study was to establish if the different disequilibrium offsets from seawater $\delta^{18} \mathrm{O}$ composition for Diploastrea heliopora and Porites affect the ability of either coral genus to record regional differences in mean SST and SSS. Examining the combined effect on coral $\delta^{18} \mathrm{O}$ of the difference in SST and SSS between New Caledonia and Alor provides a good test. According to the $\delta^{18} \mathrm{O}-\mathrm{SST}$ relation (Eqn. 1), the $4.9^{\circ} \mathrm{C}$ difference in mean SST between New Caledonia and Alor should produce a shift in coral $\delta^{18} \mathrm{O}$ of $0.88 \%$ (Table 1). Likewise, according to the $\delta^{18} \mathrm{O}$-SSS relation (Eqn. 2), the difference in mean SSS between the two regions (1.4 PSU) should shift the coral $\delta^{18} \mathrm{O}$ by an additional $0.38 \%$ (Table 1 ). Therefore, the combined effect of the difference in mean SST and SSS on coral $\delta^{18} \mathrm{O}$ would be to lower Alor coral $\delta^{18} \mathrm{O}$ by $1.26 \%$ relative to coral $\delta^{18} \mathrm{O}$ from New Caledonia.

The regional difference in mean coral $\delta^{18} \mathrm{O}$ indicated by the Diploastrea records from New Caledonia and Alor is $1.24 \%$, which is essentially the same as the calculated difference of 1.26\% (Fig. 7; Table 1). The regional difference in mean $\delta^{18} \mathrm{O}$ indicated by the pair of Porites is only $1.10 \%$, which is $0.16 \%$ less than the anticipated difference. While it is not possible to quantify the significance of this mismatch for Porites, some of the $0.16 \%$ difference may be due to interlaboratory differences in calibration to NBS-19 (Ostermann and Curry, 2000). However, it is also possible that differences in oxygen isotope disequilibrium among individual species within the genus Porites are responsible for some of the mismatch. This cannot be the case for the coral genus Diploastrea, which comprises only one species throughout its known range of survival. The results suggest that slow-growing colonies of Diploastrea appear to faithfully track regional differences in mean SST and $\delta^{18} \mathrm{O}_{\mathrm{w}}$ at least as well as Porites.

\subsection{Reconstructing ENSO in the Western Pacific}

The ability of $\delta^{18} \mathrm{O}$ in the coral genera Porites and Pavona to monitor interannual climate fluctuations in the tropical Pacific region, such as the El Niño-Southern Oscillation (ENSO), has been demonstrated with live coral specimens (e.g., Cole et al., 1993; Dunbar et al., 1994; Evans et al., 1998; Guilderson and Schrag, 1999; Urban et al., 2000) and fossil corals for time-slices since the Last Interglacial (Hughen et al., 1999; Corrège et al., 2000; Tudhope et al., 2001). This study was designed to directly compare records of Diploastrea and Porites in the 
ENSO-sensitive area of the southwestern Pacific (Rasmusson and Carpenter, 1982; Ropelewski and Halpert, 1987) in order to judge the ability of Diploastrea to record interannual climate variability. El Niño events (when eastern equatorial Pacific SSTs are unusually warm) are typically associated with cooler SSTs (Rasmusson and Carpenter, 1982) and below average monsoon rainfall (Ropelewski and Halpert, 1987) in the southwestern Pacific region. In contrast, changes in SSTs in the southwestern Pacific are less marked during La Niña events (when the eastern equatorial Pacific is cooler than average), but rainfall is enhanced because of a more vigorous summer monsoon. The effect of ENSO-induced changes in SST and the amount of ${ }^{18} \mathrm{O}$-depleted rainfall diluting the surface-ocean drives coral $\delta^{18} \mathrm{O}$ in the same direction, thus increasing the significance with which $\delta^{18} \mathrm{O}$ detects ENSO events.

Figure 8 shows the timing and magnitude of ENSO-induced variability in $\delta^{18} \mathrm{O}$ for the Diploastrea and Porites from New Caledonia and Alor over the period 1980-1999. The regional effect of ENSO on the coral $\delta^{18} \mathrm{O}$ is evident. During the strong El Niño events of 1986-87 and 1992-94, the combined effect of cooler SST and reduced monsoon rainfall (higher $\delta^{18} \mathrm{O}_{\mathrm{w}}$ ) serve to increase coral $\delta^{18} \mathrm{O}$ simultaneously at New Caledonia and Alor. Lower coral $\delta^{18} \mathrm{O}$ values are evident at both sites during the 1988-89 La Niña, when warmer SSTs and higher monsoon rainfall (lower $\delta^{18} \mathrm{O}_{\mathrm{w}}$ ) prevailed. The Alor Diploastrea also records the very strong El Niño event in 1982-83, but evidently the effects of this event are not as pronounced in the coral records or instrumental records (Fig. 5) for subtropical New Caledonia. The results indicate that Diploastrea heliopora records ENSO climate variability in a matter similar to Porites.

\section{SUMMARY AND CONCLUSIONS}

Based on our examination of skeletal $\delta^{18} \mathrm{O}$ in Diploastrea heliopora from New Caledonia and Alor, Indonesia, it appears that this slow-growing, long-lived reef-building coral has the potential to provide an important new archive of tropical climate variability. Individual colonies of Diploastrea are known to grow 3 to $4 \mathrm{~m}$ high and could potentially double the typical timespan of existing coral paleoclimate records. The concentration of Diploastrea in the Indo-Pacific region, particularly in the Warm Pool, means that these long records will describe temperature and rainfall variability for a key component of the global climate system. The tough, dense, dome-shaped colonies of Diploastrea preserve well in the fossil record, offering the potential for long paleoclimate records for time-slices from the distant past.

Specific conclusions from this study are:

1. Seasonal oxygen isotope and carbon isotope signals extracted from the septal portion of the skeleton of Diploastrea were significantly smoothed and distorted relative to signals from the columellar area of the corallite. Microanalysis of the columellar portion of Diploastrea produced isotopic data similar in quality to that extracted from the Porites coral archive. Bulk sampling of the complex skeletal architecture of Diploastrea will undoubtedly produce artifacts in paleoclimate reconstructions, and should be avoided.

2. Oxygen isotope ratios analyzed in the columellar skeleton in Diploastrea exhibit a $\delta^{18} \mathrm{O}$-temperature dependence that is similar to that reported for Porites. The slope of the $\delta^{18} \mathrm{O}$-temperature calibration for Diploastrea $\left(-0.18 \% /{ }^{\circ} \mathrm{C}\right)$ is in good agreement with that derived for a nearby Porites $\left(-0.19 \% /{ }^{\circ} \mathrm{C}\right.$; Quinn et al., 1996), based on comparisons with an in situ SST record from Amédée Lighthouse, New Caledonia.

3. There is a measurable difference of $0.3 \pm 0.1 \%$ between the kinetic / biological disequilibrium offsets from seawater $\delta^{18} \mathrm{O}$ composition for Diploastrea and Porites. Despite the difference in the disequilibrium offset of the $\delta^{18} \mathrm{O}$ records for Diploastrea and Porites, the 
columellar skeletal $\delta^{18} \mathrm{O}$ of Diploastrea is capable of accurately recording regional differences in mean temperature and salinity throughout the southwestern Pacific. We also tested the ability of Diploastrea to record the combined effect on skeletal $\delta^{18} \mathrm{O}$ of changes in SST and precipitation in the ENSO-sensitive southwestern Pacific region. The results suggest that Diploastrea records interannual climate variability as well as Porites and that it should yield a dependable paleo-ENSO signal.

Further experiments with Diploastrea heliopora should result in improved paleoclimate reconstructions. The potential for interspecies offsets in isotope ratios among coral records is now well known, thus a key advantage to working with Diploastrea is that a single species represents the genus throughout its entire environmental range of survival, and long fossil history. Furthermore, intercomparison of geochemical records among Porites has not been straightforward because the positioning of sampling transects within a coral core is a matter of interpretation, and can potentially affect the quality of the resulting geochemical record. The individual corallites of Diploastrea are long and straight, thus offering the opportunity to produce continuous records spanning centuries from a single corallite. Microsampling restricted to the columella of Diploastrea should improve the standardization and intercomparison of coral geochemical records produced in different laboratories.

Acknowledgments - We wish to thank Yvan Join and Jean Louis Laurent for collecting the New Caledonia Diploastrea and Bambang Suwargadi (LIPI), Stewart Fallon (RSES), and Donovan and Graeme Whitford (Kupang Dive Pty. Ltd.) for help with coral drilling in Alor. We sincerely thank Aiko Watanabe for coral sample preparation and Joe Cali for facilitating the mass spectrometry. We are also grateful to two anonymous reviewers and Associate Editor, David Lea, for providing helpful suggestions that improved the manuscript.

\section{REFERENCES}

Aharon P. (1991) Recorders of reef environment histories: stable isotopes in corals, giant clams, and calcareous algae. Coral Reefs 10, 71-90.

Barnes D. J. and Lough J. M. (1993) On the nature and causes of density banding in massive coral skeletons. J. Exp. Mar. Biol. Ecol. 167, 91-108.

Böhm F., Joachimski M. M., Lehnert H., Morgenroth G., Kretschmer W., Vacelet J. and Dullo W.-C. (1996) Carbon isotope records from extant Caribbean and South Pacific sponges: Evolution of $\delta^{13} \mathrm{C}$ in surface water DIC. Earth Planet. Sci. Lett. 139, 291-303.

Böhm F., Joachimski M. M., Dullo W.-C., Eisenhauer A., Lehnert H., Reitner J. and Wöerhide G. (2000) Oxygen isotope fractionation in marine aragonite of coralline sponges. Geochim. Cosmochim. Acta 64, 1695-1703.

Burr G. S., Beck J. W., Taylor F. W., Récy J., Edwards R. L., Cabioch G., Corrège T., Donahue D. J. and O'Malley J. M. (1998) A high resolution radiocarbon calibration between 11,700 and 12,400 calendar years BP derived from ${ }^{230} \mathrm{Th}$ ages of corals from Espiritu Santo Island, Vanuatu. Radiocarbon 40, 1093-1105.

Cabioch G., Taylor F. W., Récy J., Edwards R. L., Gray S. C., Faure G., Burr G. and Corrège T. (1998) Environmental and tectonic influences on growth and internal structure of a fringing reef at Tasmaloum (SW Espiritu Santo, New Hebrides Island Arc, SW Pacific). In: Reefs and carbonate platforms of the Pacific and Indian Ocean. (eds. G. Camoin and P. J. Davies). Int. Assoc. Sediment. Spec. Publ., 25, 261-277.

Chappell J. (1974) Geology of coral terraces, Huon Peninsula, New Guinea: A study of Quaternary tectonic movements and sea-level changes. Bull. Geol. Soc. Amer. 85, 553-570. 
Chappell J. and Veeh H. H. (1978) Late Quaternary tectonic movements and sea-level changes at Timor and Atauro Island. Bull. Geol. Soc. Amer. 89, 356-368.

Cohen A. L. and Hart S. R. (1997) The effect of colony topography on climate signals in coral skeleton. Geochim. Cosmochim. Acta 61, 3905- 3912.

Cole J. E., Fairbanks R. G. and Shen G. T. (1993) The spectrum of recent variability in the Southern Oscillation: results from a Tarawa Atoll coral. Science 262, 1790-1793.

Corrège T., Delcroix T., Récy J., Beck J. W., Cabioch G. and Le Cornec F. (2000) Evidence for stronger El Niño-Southern Oscillation (ENSO) events in a mid-Holocene massive coral. Paleoceanography 15, 465-470.

de Villiers S., Nelson B. K. and Chivas A. R. (1995) Biological controls on coral Sr/Ca and $\delta^{18} \mathrm{O}$ reconstruction of sea surface temperatures. Science 269, 1247-1249.

Druffel E. R. and Griffin S. (1993) Large variation of surface ocean radiocarbon: Evidence of circulation changes in the Southwestern Pacific. J. Geophys. Res. 98, 20,249-20,259.

Dunbar R. B. and Cole J. E. (1999) Annual Records of Tropical Systems (ARTS). PAGES Workshop Report Series 99, 72.

Dunbar R. B., Wellington G. M., Colgan M. W. and Glynn P. W. (1994) Eastern Pacific sea surface temperature since 1600 A.D.: The $\delta^{18} \mathrm{O}$ record of climate variability in Galapagos corals. Paleoceanography 9, 291-315.

Epstein S. R. and Mayeda T. (1953) Variations of ${ }^{18} \mathrm{O}$ content of waters from natural sources. Geochim. Cosmochim. Acta 4, 213-224.

Epstein S. R., Buchsbaum H. A., Lowenstam H. and Urey H. C. (1951) Carbonate-water isotopic temperature scale. Bull. Geol. Soc. Amer. 64, 417-426.

Erez J. (1978) Vital effect on stable-isotope composition seen in foraminifera and coral skeletons. Nature 273, 199-202.

Evans M. N., Fairbanks R. G. and Rubenstone J. L. (1998) A proxy index of ENSO teleconnections. Nature 394, 732-733.

Fairbanks R. G., Evans M. N., Rubenstone J. L., Mortlock R. A., Broad K., Moore M. D. and Charles C. D. (1997) Evaluating climate indices and their geochemical proxies measured in corals. Coral Reefs 16, 93-100.

Gagan M. K., Chivas A. R. and Isdale P. J. (1994) High resolution isotopic records from corals using ocean temperature and mass-spawning chronometers. Earth Planet. Sci. Lett. 121, 549-558.

Gagan M. K., Ayliffe L. K., Beck J. W., Cole J. E., Druffel E. R. M., Dunbar R. B. and Schrag D. P. (2000) New views of tropical paleoclimates from corals. Quat. Sci. Rev. 19, 45-64.

Goreau T. J. (1997) Coral skeletal chemistry: Physiological and environmental regulation of stable isotopes and trace elements in Montastrea annularis. Proc. Roy. Soc. Lond. (Ser. B) 196, 291-315.

Guilderson T. P. and Schrag D. P. (1999) Reliability of coral isotope records from the western Pacific warm pool: A comparison using age-optimized records. Paleoceanography 14, 457-464.

Hantoro W. S., Pirazzoli P. A., Jouannic C., Faure H., Hoang C. T., Radtke U., Causse C., Borel Best M., LaFont R., Bieda S. and Lambeck K. (1994) Quaternary uplifted coral terraces on Alor Island, east Indonesia. Coral Reefs 13, 215-223.

Heikoop J. M., Dunn J. J., Risk M. J., Schwarcz H. P., McConnaughey T. A., and Sandeman I. M. (2000) Separation of kinetic and metabolic isotope effects in carbon-13 records preserved 
in reef coral skeletons. Geochim. Cosmochim. Acta 64, 975-987.

Hendy E. J., Gagan M. K., Alibert C., McCulloch M. T., Lough J. M. and Isdale P. J. (2002) Abrupt shift in tropical sea surface salinity at end of Little Ice Age. Science 295, 1511-1514.

Hughen K. A., Schrag D. P., Jacobsen S. B. and Hantoro W. S. (1999) El Niño during the last interglacial period recorded by a fossil coral from Indonesia. Geophys. Res. Lett. 26, 3129-3132.

Land L. S., Lang, J. C. and Barnes, D. J. (1975) Extension rate: A primary control on the isotopic composition of West Indian (Jamaican) scleractinian reef coral skeletons. Mar. Biol. 33, 221-233.

Leder J. J., Swart P. K., Szmant A. M. and Dodge R. E. (1996) The origin of variations in the isotopic record of scleractinian corals: I. Oxygen. Geochim. Cosmochim. Acta 60, 2857-2870.

Linsley B. K., Dunbar R. B., Wellington G. M. and Mucciarone D. A. (1994) A coral-based reconstruction of Intertropical Convergence Zone variability over Central America since 1707. J. Geophys. Res. 99, 9977-9994.

Linsley B. K., Messier R. G. and Dunbar R. B. (1999) Assessing between-colony oxygen isotope variability in the coral Porites lobata at Clipperton Atoll. Coral Reefs 18, 13-27.

Lough J. M. and Barnes D. J. (1997) Several centuries of variation in skeletal extension, density and calcification in massive Porites colonies from the Great Barrier Reef: A proxy for seawater temperature and a background of variability against which to identify unnatural change. J. Exp. Mar. Biol. Ecol. 211, 29-67.

McConnaughey T. (1989a) ${ }^{13} \mathrm{C}$ and ${ }^{18} \mathrm{O}$ isotopic disequilibrium in biological carbonates: I Patterns. Geochim. Cosmochim. Acta 53, 151-162.

McConnaughey T. (1989b) ${ }^{13} \mathrm{C}$ and ${ }^{18} \mathrm{O}$ isotopic disequilibrium in biological carbonates: II In vitro simulation of kinetic isotope effects. Geochim. Cosmochim. Acta 53, 163-171.

Moore M. D., Charles C. D., Rubenstone J. L. and Fairbanks R. G. (2000) U/Th-dated sclerosponges from the Indonesian Seaway record subsurface adjustments to west Pacific winds. Paleoceanography 15, 404-416.

Ostermann D. R. and Curry W. B. (2000) Calibration of stable isotopic data: An enriched delta ${ }^{18} \mathrm{O}$ standard used for source gas mixing detection and correction. Paleoceanography 15, 353-360.

Paillard, D., Labeyrie, L. and Yiou, P. (1996) Macintosh program performs time-series analysis, Eos Trans. $A G U, 77: 379$.

Pätzold, J. (1992) Variation of stable oxygen and carbon isotopic fractionation within the skeletal elements of reef building corals from Bermuda. Proc. 7th Int. Coral Reef Symp. Guam 1, 196-200.

Pirazzoli P. A., Radtke U., Hantoro W. S., Jouannic C., Hoang C. T., Causse C. and Borel B. M. (1991). Quaternary raised coral-reef terraces on Sumba Island, Indonesia. Science 252, 1834-1836.

Quinn T. M., Taylor F. W., Crowley T. J. and Link S. M. (1996) Evaluation of sampling resolution in coral stable isotope records: A case study using records from New Caledonia and Tarawa. Paleoceanography 11, 529-542.

Quinn T. M., Crowley T. J., Taylor F. W., Henin C., Joannot P. and Join Y. (1998) A multi-century stable isotope record from a New Caledonia coral: Interannual and decadal sea-surface temperature variability in the southwest Pacific since 1657 A.D. Paleoceanography 13, 412-426. 
Rasmusson, E. M. and Carpenter T. H. (1982) Variations in tropical sea surface temperature and surface wind fields associated with the Southern Oscillation / El Niño. Mon. Wea. Rev. 110, 354-384.

Reynolds R. W. and Smith T. M. (1994) Improved global sea surface temperature analysis using optimum interpolation. J. Climate 7, 929-948.

Ropelewski, C. F. and Halpert, M. S. (1987) Global and regional scale precipitation patterns associated with the El Niño / Southern Oscillation. Mon. Wea. Rev. 115, 1606-1626.

Socki R. A., Karlsson H. R. and Gibson Jr. E. K. (1992) Extraction technique for the determination of oxygen-18 in water using preevacuated glass vials. Anal. Chem. 64, 829-831.

Swart P. K. (1983) Carbon and oxygen isotope fractionation in scleractinian corals: A review. Earth Sci. Rev. 19, 51-80.

Swart P., Moore M. D., Charles C. D. and Böhm F. (1998) Sclerosponges may hold new keys to marine paleoclimate. EOS Trans. AGU 79, 633-636.

Tudhope A. W., Chilcott C. P., McCulloch M. T., Cook E. R., Chappell J., Ellam R. M., Lea D. W., Lough J. M. and Shimmield G. B. (2001) Variability of the El Niño-Southern Oscillation through a glacial-interglacial cycle. Science 291, 1511-1517.

Urban F. E., Cole J. E. and Overpeck J. T. (2000) Influence of mean climate change on climate variability from a 155-year tropical Pacific coral record. Nature 407, 989-993.

Veron J. E. N. (2000) Corals of the World. Australian Institute of Marine Science, Townsville.

Watanabe T., Winter A. and Oba T. (2000) Seasonal changes in sea surface temperature and salinity during the Little Ice Age in the Caribbean Sea deduced from $\mathrm{Mg} / \mathrm{Ca}$ and ${ }^{18} \mathrm{O} /{ }^{16} \mathrm{O}$ ratios in corals. Mar. Geol. 173, 21-35.

Watanabe T., Winter A., Oba T., Anzai R. and Ishioroshi H. (2002) Evaluation of the fidelity of isotope records as an environmental proxy in the coral Montastraea. Coral Reefs 21, 169-178.

Weber J. N. and Woodhead P. M. J. (1972) Temperature dependence of oxygen-18 concentration in reef coral carbonates. J. Geophys. Res. 77, 463-473.

Wellington G. M., Dunbar R. B. and Merlen G. (1996) Calibration of stable oxygen isotope signatures in Galapagos corals. Paleoceanography 11, 467-480.

Winter A., Ishioroshi H., Watanabe T., Oba T. and Christy J. R. (2000) A two-to-three degree cooling of Caribbean Sea surface temperatures during the Little Ice Age. Geophys. Res. Lett. 27, 3365-3368.

\section{TABLE}

Table 1. Comparison of differences in mean SST and SSS for Amédée, New Caledonia and Alor, Indonesia, and differences in mean $\delta^{18} \mathrm{O}$ recorded by Diploastrea heliopora and Porites.

\begin{tabular}{lcccc}
\hline $\begin{array}{l}\text { Location / } \\
\text { Calculations }\end{array}$ & SST & SSS & $\begin{array}{c}\delta^{18} \mathrm{O}(\text { Porites }) \\
(\%)\end{array}$ & $\begin{array}{c}\delta^{18} \mathrm{O} \text { (Diploastrea) } \\
(\%)\end{array}$ \\
\hline New Caledonia & $23.4^{\circ} \mathrm{C}$ & $35.7 \mathrm{psu}$ & -4.42 & -4.03 \\
Alor, Indonesia & $28.3^{\circ} \mathrm{C}$ & $34.3 \mathrm{psu}$ & -5.52 & -5.27 \\
$\begin{array}{l}\text { Measured } \Delta \\
\text { (New Caledonia - Alor) }\end{array}$ & $4.9^{\circ} \mathrm{C}$ & $1.4 \mathrm{psu}$ & 1.10 & 1.24
\end{tabular}


\begin{tabular}{lcccc} 
Calculated $\Delta \delta^{18} \mathrm{O}$ & $0.88 \% \mathrm{o}^{\mathrm{a}}$ & $0.38 \%{ }^{\mathrm{b}}$ & 1.26 & 1.26 \\
$\begin{array}{l}\text { Difference } \\
\text { (measured - calculated) }\end{array}$ & ----- & ----- & 0.16 & 0.02 \\
\hline
\end{tabular}

a Calculated $\Delta \delta^{18} \mathrm{O}=\Delta_{\text {(New Caledonia - Alor })} *\left[0.18 \%{ }^{\circ} \mathrm{C}\right]$.

b Calculated $\Delta \delta^{18} \mathrm{O}=\Delta_{\text {(New Caledonia-Alor) }} *[0.27 \%$ /PSU $]$. The accuracy of the calculated $\Delta \delta^{18} \mathrm{O}$ (based on the difference in mean salinity between New Caledonia and Alor) was checked with spot measurements of $\delta^{18} \mathrm{O}_{\mathrm{w}}$ at Amédée, New Caledonia, and Pantai Putih, Alor, in September-December, 1999. The mean $\delta^{18} \mathrm{O}_{\mathrm{w}}$ for Amédée was $0.53 \pm 0.06 \%(n=4)$ while the $\delta^{18} \mathrm{O}_{\mathrm{w}}$ value for Pantai Putih was $0.02 \pm 0.02 \%(n=2)$. The measured difference in $\delta^{18} \mathrm{O}_{\mathrm{w}}$ of $0.51 \%$ is consistent with the calculated $\Delta \delta \delta^{\circ} \mathrm{O}$ of $0.38 \%$.

\section{FIGURE CAPTIONS}

Figure 1. Location of sampling sites for comparison of oxygen isotope ratios in Diploastrea heliopora and Porites: Southwest Lagoon near Amédée, New Caledonia and Pantai Putih, Alor, Indonesia. Dashed line shows the known range of Diploastrea heliopora (Veron, 2000) in relation to the Western Pacific Warm Pool (mean SST $>28^{\circ} \mathrm{C}$; http://iridl.ldeo.columbia.edu/SOURCES/.NOAA/.NCEP/.EMC/.CMB/.GLOBAL/.Reyn_SmithOI v2/.climatology/.sst).

Figure 2. X-radiograph positive prints of coral density banding showing difference in growth rates for the Porites from Alor ( $\sim 20 \mathrm{~mm} / \mathrm{y}$; left) and Diploastrea heliopora from New Caledonia $(\sim 3 \mathrm{~mm} / \mathrm{y}$; right). Couplets of high skeletal density (dark bands) and low skeletal density (light bands) represent one annual growth increment. (Far right) Schematic diagram of coral ledge configuration and micromilling technique used for high-resolution microsampling of transects within the columellar and septal areas of Diploastrea.

Figure 3. Comparison of seasonal range in skeletal $\delta^{18} \mathrm{O}$ and $\delta^{13} \mathrm{C}$ for high-resolution sampling transects from the columellar (solid line) and septal (dashed line) areas of the Diploastrea heliopora from Amédée, New Caledonia. The smoothing and offset of the seasonal $\delta^{18} \mathrm{O}$ and $\delta^{13} \mathrm{C}$ signals in the septal area is caused by the $\sim 45^{\circ}$ slope and thickening of septal skeletal elements through time (averaging of signal). Years are labeled in $\delta^{18} \mathrm{O}$ profile (1991-95) to show $\sim 6$ to 12-month offset (one-half to one seasonal cycle) between data collected from septal and columellar transects.

Figure 4. Comparison of columellar skeletal $\delta^{18} \mathrm{O}$ records and growth rates for Diploastrea heliopora and Porites corals from Amédée, New Caledonia and Pantai Putih, Alor. Horizontal lines show mean $\delta^{18} \mathrm{O}$ values for each record. The difference in the disequilibrium offset from seawater $\delta^{18} \mathrm{O}$ composition for Diploastrea and Porites $(\Delta \mathrm{K})$ is $0.39 \%$ at New Caledonia and 0.25\% at Alor. Data for Porites from New Caledonia are from Quinn et al., 1996.

Figure 5. Time-series of columellar skeletal $\delta^{18} \mathrm{O}$ in Diploastrea heliopora compared with mean monthly SST and SSS measured in situ at Amédée, New Caledonia. The timing and pattern of skeletal $\delta^{18} \mathrm{O}$ and reef SST correlate during periods when SSS, and presumably seawater $\delta^{18} \mathrm{O}$, are relatively constant. Coral $\delta^{18} \mathrm{O}$ values are reversed on $\mathrm{Y}$ axis for direct comparison with SST (warmer upward).

Figure 6. Least squares linear regression of columellar skeletal $\delta^{18} \mathrm{O}$ and SST for Diploastrea heliopora from Southwest Lagoon near Amédée, New Caledonia, over the period 1980 to 1996. 
The $\delta^{18} \mathrm{O} / \mathrm{SST}$ relationship of $-0.18 \% /{ }^{\circ} \mathrm{C}$ for the Diploastrea was derived using two months defining each maximum and minimum (solid circles) in the columellar skeletal $\delta^{18} \mathrm{O}$ profile. Open circles are data points excluded from the regression analysis because of chronological uncertainties in spring and autumn produced by simple linear interpolation between $\delta^{18} \mathrm{O}$ maxima and minima. The $\delta^{18} \mathrm{O} / \mathrm{SST}$ slope for Diploastrea is similar to that published for a nearby Porites (dashed line; $-0.19 \%{ }^{\circ} \mathrm{C}$ ) from Amédée (Quinn et al., 1996).

Figure 7. Summary of annual average columellar skeletal $\delta^{18} \mathrm{O}$ for Diploastrea heliopora and Porites versus coral annual extension rate. Despite the different kinetic disequilibrium effect on $\delta^{18} \mathrm{O}$ for Diploastrea and Porites, both corals record a similar shift in coral $\delta^{18} \mathrm{O}\left(\Delta \delta^{18} \mathrm{O}\right)$ between New Caledonia and Alor. The magnitudes of the shifts in coral $\delta^{18} \mathrm{O}(1.2 \%$ for Diploastrea; $1.1 \%$ for Porites) are consistent with the shift of $1.3 \%$ for coral $\delta^{18} \mathrm{O}$ calculated using the measured difference in mean SST and SSS between New Caledonia and Alor (see Table 1).

Figure 8. Comparison of ENSO-related interannual variability in $\delta^{18} \mathrm{O}$ for Diploastrea heliopora (solid lines with closed circles) and Porites (dashed lines with open circles) from New Caledonia and Alor. The coral records are interpolated to a resolution of 12 samples per year (Paillard et al., 1996) and then smoothed with a 48 point running average (thick solid lines) to remove the annual cycle in $\delta^{18} \mathrm{O}$. Coral $\delta^{18} \mathrm{O}$ values are reversed on $\mathrm{Y}$ axis to show warmer/wetter conditions upward. Shading indicates periods of cooler SST and higher salinity (higher $\delta^{18} \mathrm{O}$ values) in the western Pacific region associated with El Niño events. 


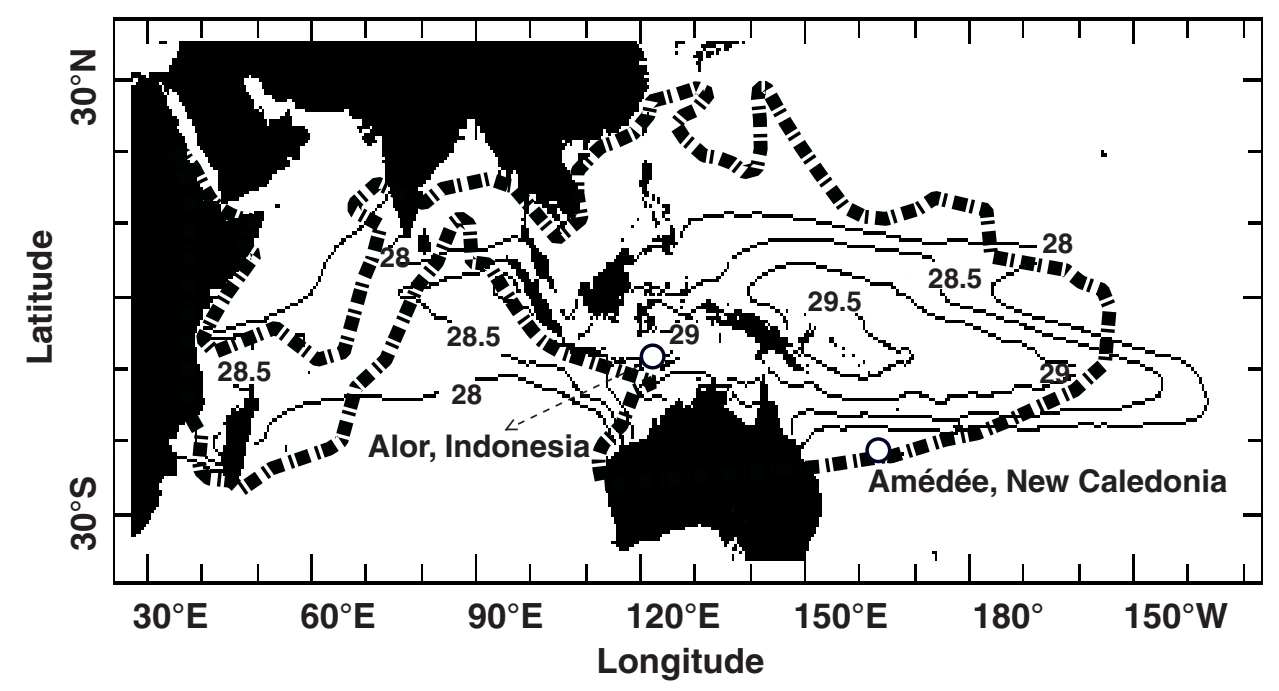

Fig. 1 

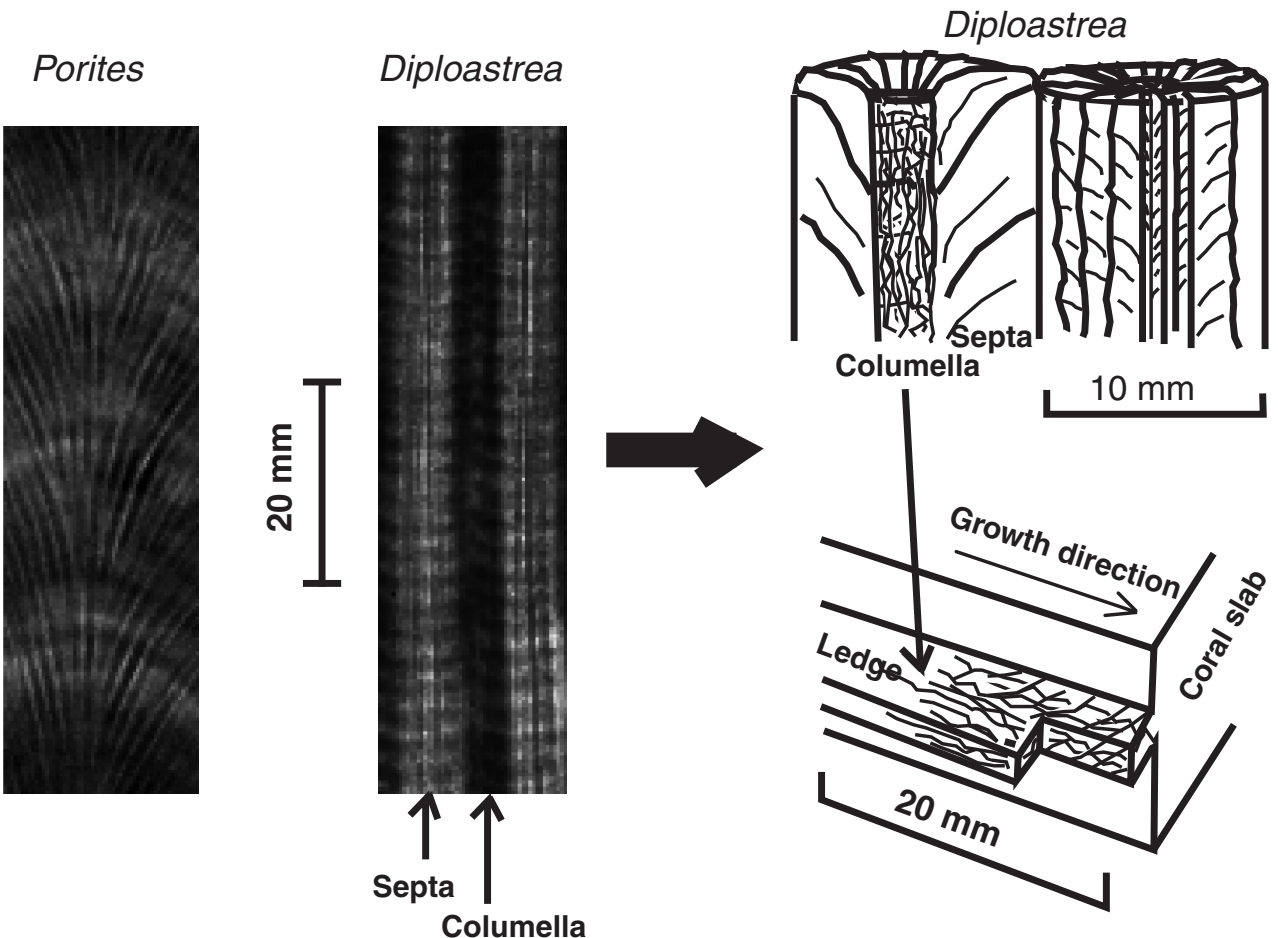

Fig. 2 


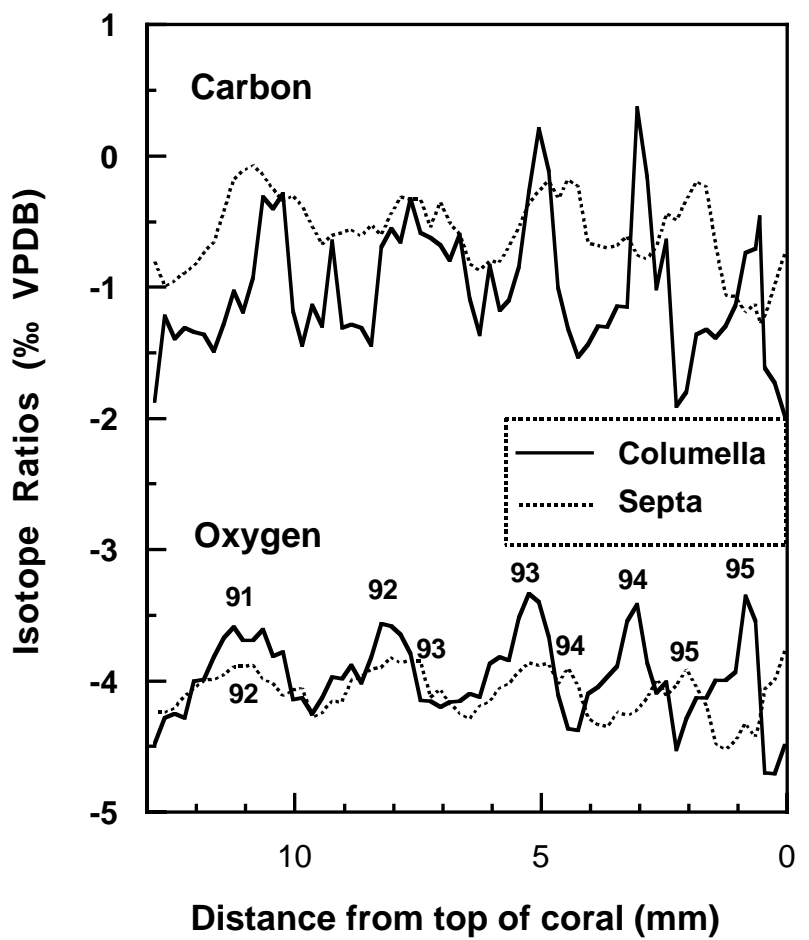

Fig. 3 


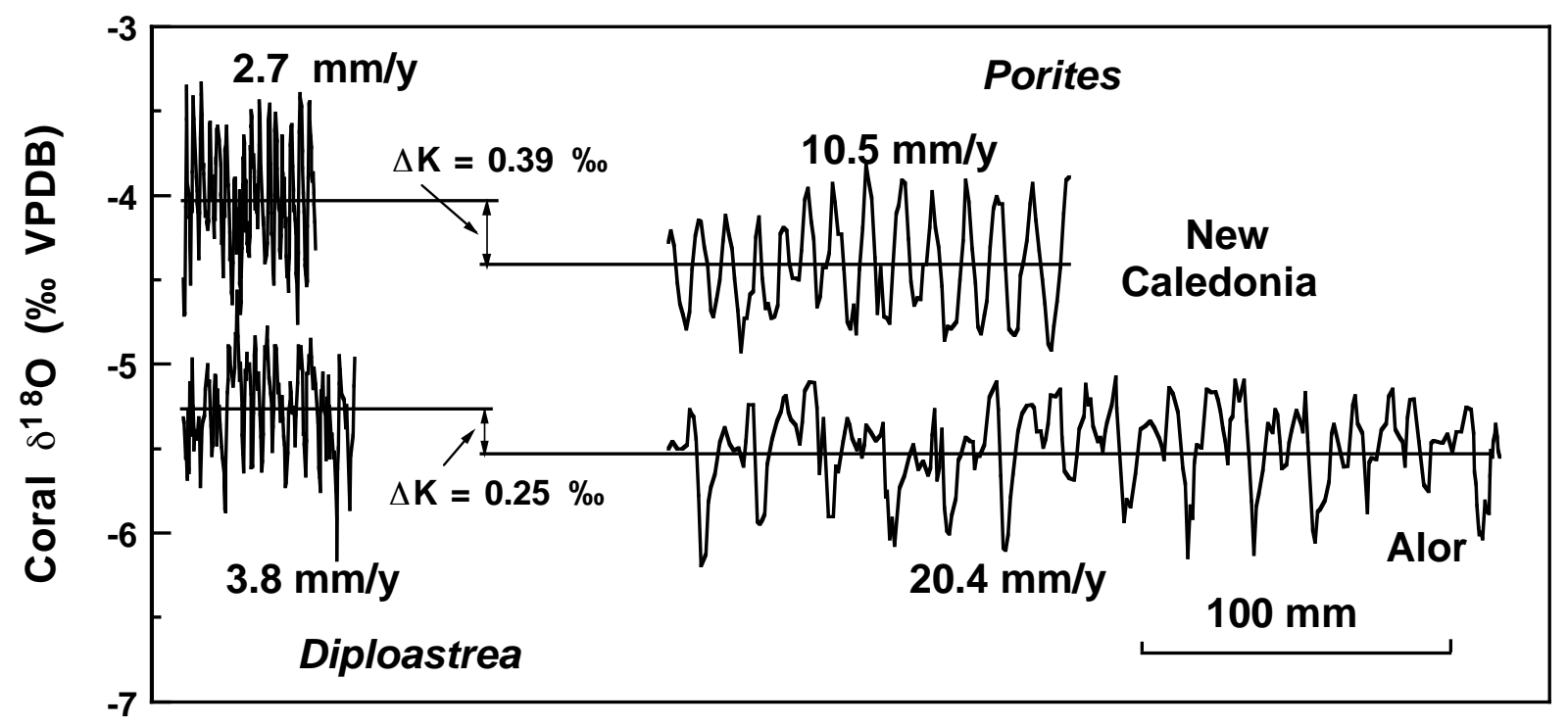

Fig. 4 


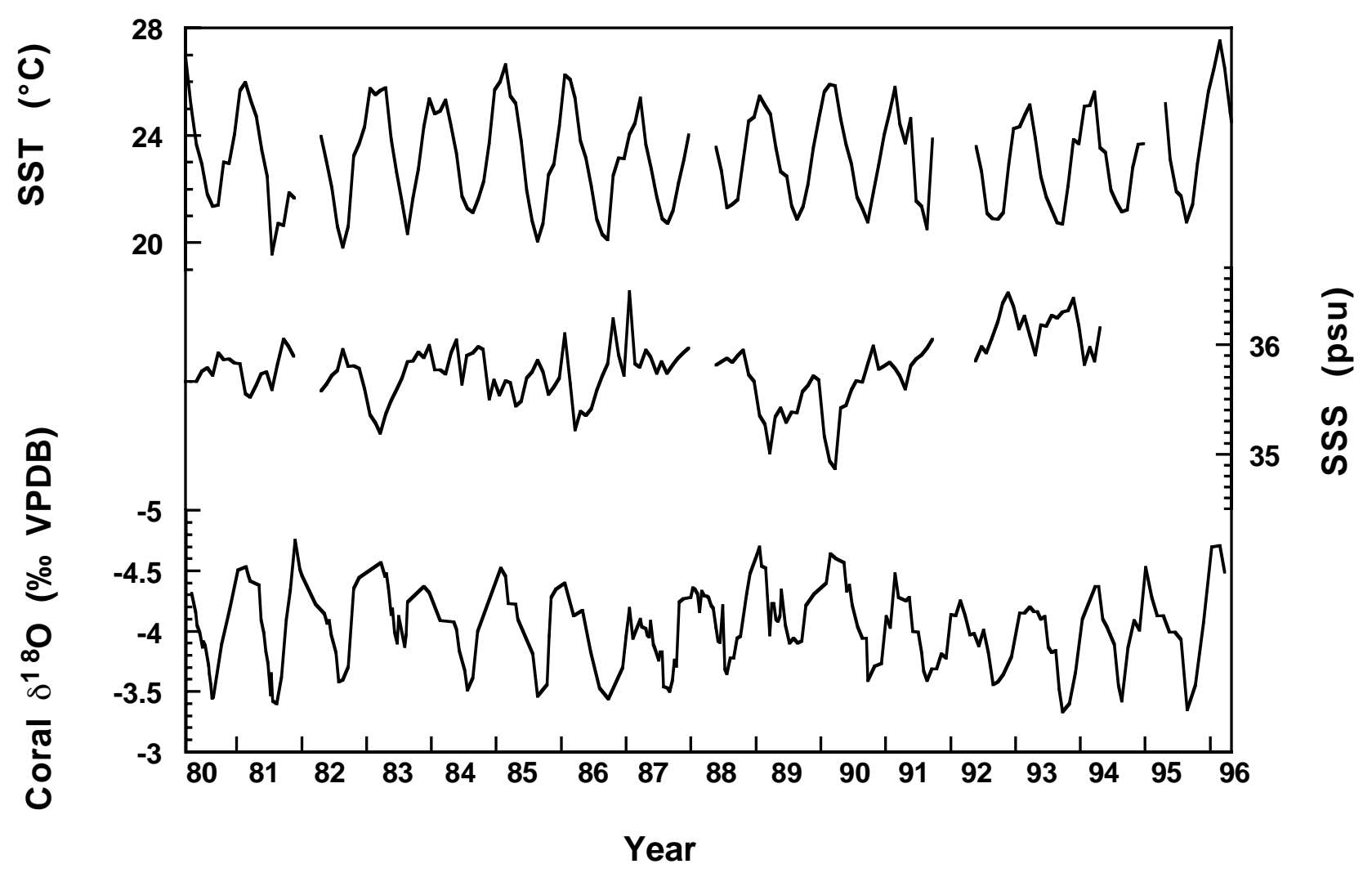

Fig. 5 


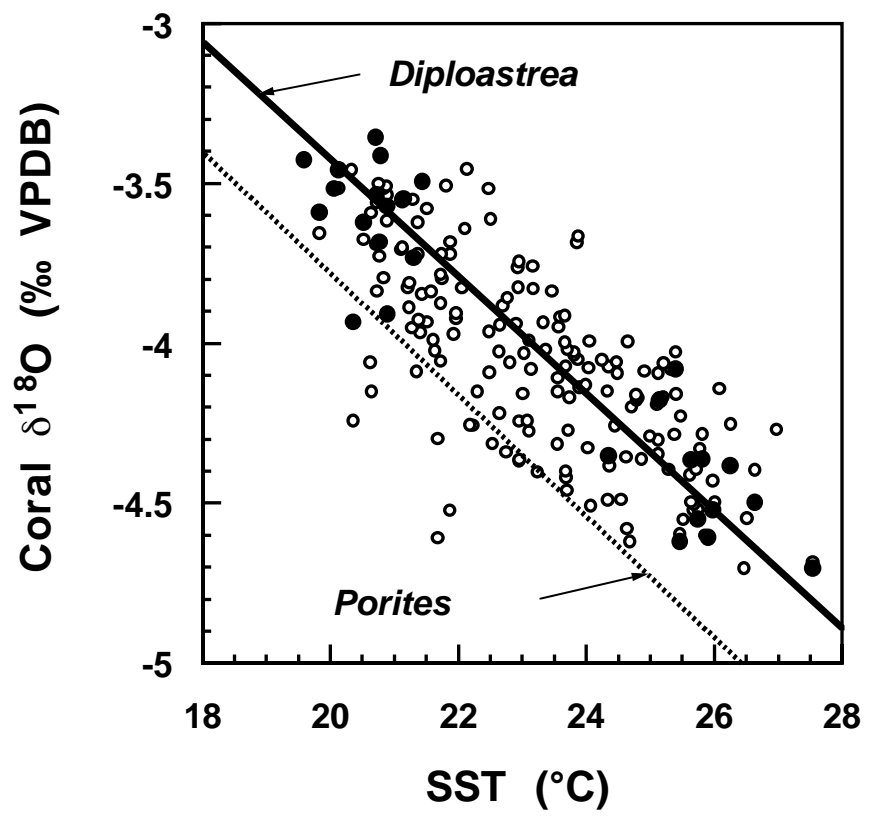

Fig. 6 


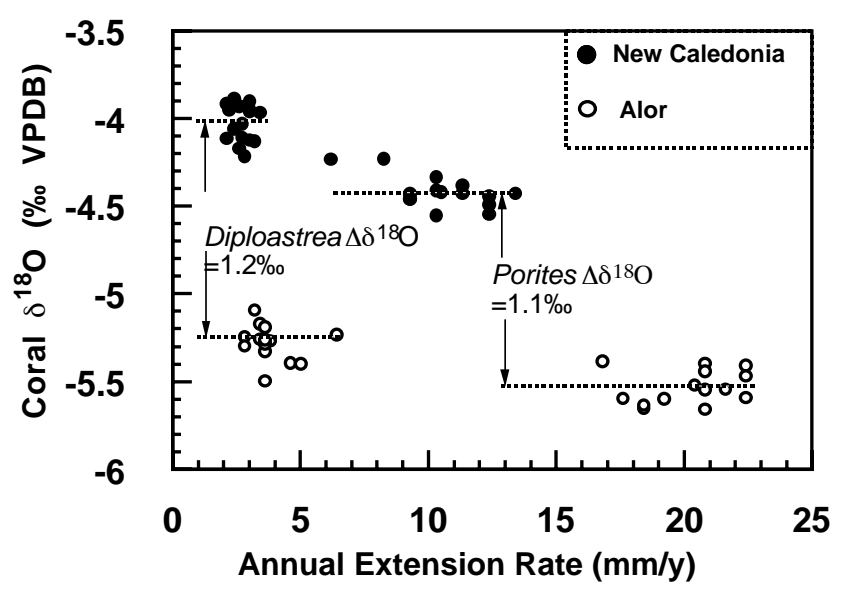

Fig. 7 


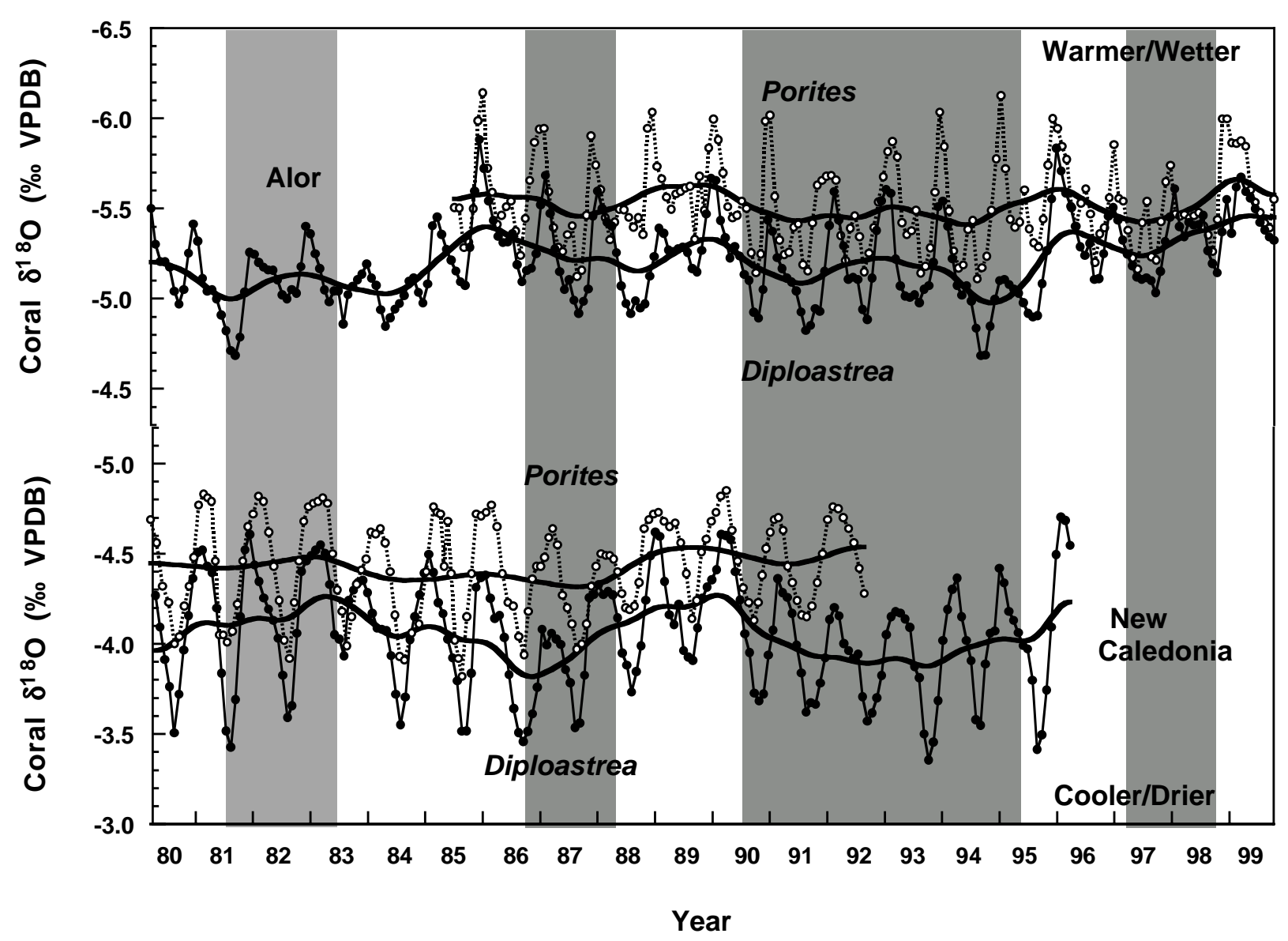

Fig. 8 